\title{
Performing in the heat: a new practical midcooling method
}

\author{
Athanasios Zavvos ${ }^{1 *}$, Panagiotis Gkrilias ${ }^{1,2}$, Niki Manolaki ${ }^{1}$, Evgenia Cherouveim¹, Maria Koskolou', \\ Nikolaos Geladas ${ }^{1}$ \\ From 15th International Conference on Environmental Ergonomics (ICEE XV) \\ Portsmouth, UK. 28 June - 3 July 2015
}

\section{Introduction}

Pre-cooling aims to decrease body core temperature prior to [1] and decelerate its rise during exercise preventing excessive hyperthermia [2]. Exercise time to exhaustion in a hot environment is inversely related to the initial body temperature and directly affected by the rate of heat storage [3]. Despite the fact that all ball games involve intermittent activity with at least one long brake among periods, the majority of existing precooling methods are applied before event initiation and use aggressive techniques (cold-water immersion, ice cubes, ice vests). This practice is cumbersome and may initially induce hypothermia, ensuing thermo genesis and discomfort. The purpose of this study was to investigate the effect of a new, practical method for cooling the body during the break (mid-cooling) of a prolonged, high-intensity intermittent exercise in the heat.

\section{Methods}

Eight healthy subjects (22 (1.7) yrs) performed, in $31{ }^{\circ} \mathrm{C}$, two experimental conditions: mid-cooling (Mid) and (Con), a 46-min intermittent exercise protocol consisting of multiple 2-min bouts ( $5 \mathrm{sec}$ sprinting on a cycle ergometer against a resistance equal to $7.5 \%$ of the subject's body weight, $105 \mathrm{sec}$ energetic rehabilitation at $35 \% \mathrm{VO}_{2 \max }$, 10sec of passive recovery) [4]. A $15 \mathrm{~min}$ break in a thermo-neutral environment $\left(26(0.58){ }^{\circ} \mathrm{C}\right.$, $50 \%(0.5) \% \mathrm{rh})$ followed, with subjects remaining idle; in Mid, they were covered with a bathrobe (body) and a towel (feet) both garments previously soaked into water of $17(0.12){ }^{\circ} \mathrm{C}$. Upon completion of the $15 \mathrm{~min}$ break, another intermittent exercise protocol, similar to the

\footnotetext{
* Correspondence: zavvosathanasios@gmail.com

'Department of Sports Medicine and Biology of Exercise, Faculty of Physical Education, and Sport Science, University of Athens, Greece

Full list of author information is available at the end of the article
}

first, was performed until rectal temperature (Tre) approached $39^{\circ} \mathrm{C}$.

\section{Results}

No differences were observed between conditions in the initial $46 \mathrm{~min}$ of exercise. The rate of rectal temperature drop $(\Delta$ Tre $)$ during the break was higher in Mid $(-0.15$ $\left.(0.02){ }^{\circ} \mathrm{C}\right)$ than in Con $\left(-0.05(0.02){ }^{\circ} \mathrm{C}\right)(\mathrm{p}=0.03)$, whereas the rate of change in skin temperature $(\Delta$ Tskin) and heart rate (HR) were similar in the two conditions. Upon completion of the second exercise period, the rise of Tre was less profound $(\mathrm{p}=0.05)$ and HR tended to be lower $(\mathrm{p}=0.12)$ in Mid $\left(0.42(0.07){ }^{\circ} \mathrm{C} ; 139(1.57)\right.$ beats. $\left.\mathrm{min}^{-1}\right)$ than in Con $\left(0.61(0.11){ }^{\circ} \mathrm{C} ; 153(1.20)\right.$ beats. $\left.\mathrm{min}^{-1}\right)$, whereas $\Delta$ Tskin did not differ between condition.

\section{Discussion}

Implementation of a "Mid" (wet bathrobe), cooling maneuver during the break between two intermittent exercise periods elicited a three times greater Tre fall. This effect was carried on to the second exercise period where the rate of Tre rise was lower, thus preventing excessive hyperthermia [5].

\section{Conclusion}

These results suggest an effective and practical midcompetition cooling maneuver.

\footnotetext{
Authors' details

${ }^{1}$ Department of Sports Medicine and Biology of Exercise, Faculty of Physical Education, and Sport Science, University of Athens, Greece. ${ }^{2}$ Technological Educational Institute (TEI) of Western Greece, Department of Physical Therapy, Aigio Achaias, Greece.
}

Published: 14 September 2015 


\section{References}

1. Nielsen B, Hales JRS, Strange $S$, et al: Human circulatory and thermoregulatory adaption with heat acclimation and exercise in a hot, dry environment. J Physiol 1993, 460:467-485.

2. Quod M, Martin D, Laursen P: Cooling athletes before competition in the heat. Sports Med 2006, 36(8):671-682.

3. Gonzalez -Alonso J, Teller C, Andersen S, et al: Influence of body temperature on the development of fatigue during prolonged exercise in the heat. J Appl Physiol 1999, 86(3):1032-1039.

4. Castle P, Macdonald L, Philp A, et al: Precooling leg muscle improves intermittent sprint exercise performance in hot, humid conditions. J Appl Physiol 2006, 100:1377-1384.

5. Barwood MJ, Davey S, House JR, Tipton MJ: Post-exercise cooling techniques in hot, humid conditions. European Journal of Applied Physiology 2009, 107(4):385-96.

doi:10.1186/2046-7648-4-S1-A130

Cite this article as: Zavvos et al.: Performing in the heat: a new practical midcooling method. Extreme Physiology \& Medicine 2015 4(Suppl 1):A130.

\section{Submit your next manuscript to BioMed Central} and take full advantage of:

- Convenient online submission

- Thorough peer review

- No space constraints or color figure charges

- Immediate publication on acceptance

- Inclusion in PubMed, CAS, Scopus and Google Scholar

- Research which is freely available for redistribution

Submit your manuscript at www.biomedcentral.com/submit
(Ciomed Central 